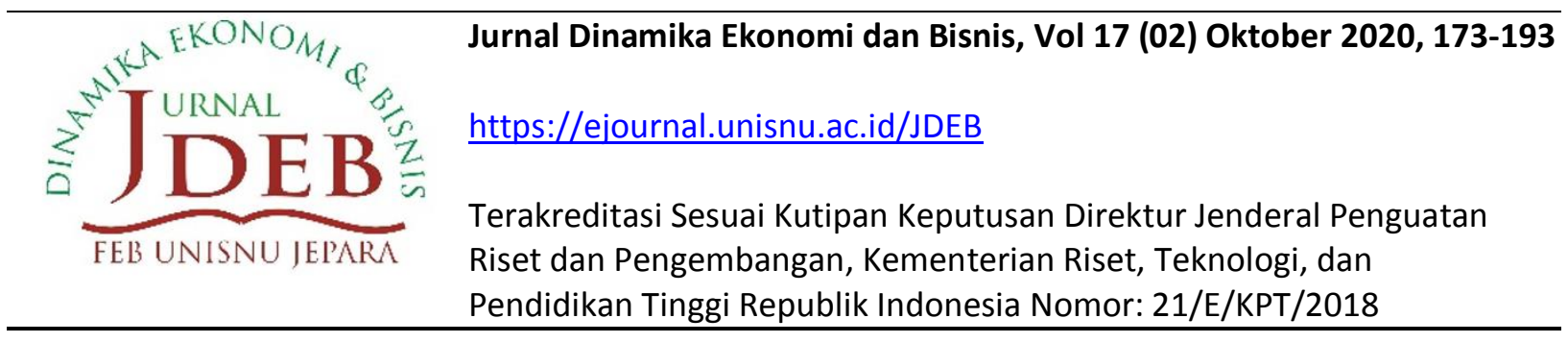

\title{
PENGARUH ROE, SIZE, DAN DER TERHADAP HARGA SAHAM PADA PERUSAHAAN PUBLIK KATEGORI RESTORAN, HOTEL, DAN PARIWISATA
}

\author{
Mora Sose Purba ${ }^{1)}$, Jamaluddin ${ }^{2)}$, Herlinta Pinem ${ }^{3)}$, Desi Roulina Sianipar ${ }^{4)}$ \\ Fakultas Ekonomi, Universitas Prima Indonesia ${ }^{1,2,3,4)}$ \\ Email: morasosepurba97@gmail.com ${ }^{1)}$, herlintapinem78@gmail.com ${ }^{3)}$,desiroulina8@gmail.com ${ }^{4)}$
}

\begin{abstract}
The increase in return on equity, company size and debt to equity ratio is not always followed by an increase in share prices in trading, service and investment companies listed on the Indonesia Stock Exchange for the 2014-2018 period. This study aims to examine and analyze how the effect of return on equity, company size and debt to equity ratio on stock prices in trading, service and investment companies listed on the Indonesia Stock Exchange for the 2014-2018 period. The research method used in this research uses quantitative research methods with descriptive quantitative research that is explanatory. The population used in this study were all trading, service and investment companies listed on the Indonesia Stock Exchange totaling 129 companies with a sample size of 39 companies with purposive sampling technique. The data analysis method used multiple linear regression.
\end{abstract}

Keywords : Return On Equity, Company Size, Debt To Equity Ratio and Stock Price

\section{Abstrak}

Kenaikan Return On Equity, ukuran perusahaan dan Debtito Equityiratio tidak selalu menyebabkan kenaikan hargaisaham perusahaan subrsektor pariwisata, restoran, serta perhotelan yang terdaftarkan Bursa EfekrIndonesia periode tahun 2014 sampai 2018. Tujuan dari pelaksanaan penelitian ini ialah untuk melaksanakan penganalisisan dan pengujian pengaruh dihasilkan oleh Return On Equity, ukuran perusahaan dan Debtito Equityiratio pada harga saham perusahaan sub-sektor pariwisata, restoran, serta perhotelan terdaftarkan Bursa EfekrIndonesia periode tahun 2014 sampai 2018. Metode yang dipergunakan ialah metode penelitianrkuantitatif denganrjenis penelitianrdeskriptif kuantitatifrbersifat Eksplanatory. Populasi yang dipergunakan keseluruhan perusahaan subrsektor pariwisata, restoran, serta perhotelan yang terdaftarkan Bursa EfekrIndonesia yang jumlahnnya 129 perusahaan dengan jumlah sampel sebanyak 14 perusahaan dengan teknik pengambilan sampel PurposiverSampling. Metode penganalisisan data mempergunakan regersi linearrberganda.

Kata Kunci: Return On Equity, Ukuran Perusahaan, Debt to Equity Ratio dan Harga Saham

Sitasi: Purba, M.S, dkk. (2020). Pengaruh ROE, Size, dan DER terhadap Harga Saham pada Perusahaan Publik Kategori Restoran, Hotel, dan Pariwisata, Jurnal Dinamika Ekonomi dan Bisnis, 17 (02) 2020, 173-193. 


\section{PENDAHULUAN}

Peningkatan dan pertumbuhan di dalam perekonomian menghasilkan suatu persaingan yang sangat kuat antar perusahaan, mencangkup pula pertumbuhan dalam bidang Perhotelan, Restoran dan Pariwisata. Pertumbuhan dan perkembangan yang sangat banyak ini menghasilkan kemungkinan untuk mengembangkan bisnis yang baik di dalam sektor jasa, dengan demikian dapat membuat para penanam modal untuk tertarik perhatiannya dalam melaksanakan penanaman modal. Hal semacam ini menghasilkan sektor jasa agar selalu melaksanakan perubahan perbaikan untuk menyediakan layanan paling baik dalam upaya untuk menaikkan mutu layanan pada public, dengan demikian perkembangan dan pertumbuhan untuk jasa akan mengalami peningkatan.

Sub sektor Perhotelan, Restoran dan Pariwisata mempunyai prospek yang baik untuk dikembangkan, hal ini disebabkan bahwa Indonesia memliki keindahan alam yang bisa dijadikan sebagai objek wisata. Dengan majunya pariwisata akan membuat Perhotelan serta Restoran secara otomatis akan mengalami kemajuan. Industri Perhotelan, Restoran dan Pariwisata berperan dalam menggerakkan pertumbuhan ekonomi serta menyediakan pengaruh positif pada keadaan ekonomi dan sosial dari rakyat dengan menyediakan pendapatan negara, menghasilkan lapangan kerja, menaikkan peluang untuk menjalankan usaha dalam sektor informal dan formal, menaikkan pendapatan untuk kepemerintahan daerah dan pusat yang bersumber dari pendapatan retribusi dan juga pajak, menaikkan perekonomian rakyat serta menjadikan pendapatan yang merata dan mampu menaikkan laba untuk perusahaan.

Sebab alasan didirikannya perusahaan adalah memperoleh laba. Kualitas laba dapat mencerminkan keadaan perusahaan apakah dapat mengembangkan dan mempertahankan usahanya. Keuntungan perusahaan di dalam setiap periode dihadarapkan meningkat, dengan demikian diperlukan perkiraan terhadap keuntungan yang hendak diraih oleh perusahaan dalam periode yang akan datang. Perkiraan berkenaan dengan keuntungan ini bisa dilaksanakan dengan melaksanakan penganalisisan terhadap laporan keuangan yang bia diperjadikan sebagai acuan dalam memprediksikan mutu keuntungan di masa depan.

Rasio Return on Equity untuk mengetahui kapasitas yang dipunyai oleh suatu perusahaan dalam menyediakan keuntungan setelah dikenai pajak dengan mempergunakan modal dari perusahaan itu sendiri. jika rasio dari return on equity ini tinggi, dengan demikian penggunaan modal sendiri yang dilaksanakan oleh manajemen perusahaan akan menjadi efisien. Jika keuntungan yang didapatkan menjadi lebih baik, dengan demikian penanam modal mendapatkan laba keuntungan yang tinggi terhadap penanaman modal yang sudah dilaksanakan.

Ukuran perusahaan menunjukkan tinggi atau rendahnya suatu perusahaan, dan sebagai indicator untuk mengukur tinggi atau rendahnya perusahaan ditinjau berdasarkan pada total asetnya. Jika asset perusahaan tertentu tinggi, dengan demikian tingkatan kinerja yang dialami oleh perusahaan akan tinggi serta menyebabkan tingkatan rasa percaya untuk para penanam modal pada perusahaan tersebut juga akan mengalami kenaikan.

Debt to Equity Ratio ialah suatu rasio yang dipergunakan untuk melaksanakan pengukuran seberapa besar suatu perusahaan dapat dilaksanakan pembiayaan dengan mempergunakan hutang. Dari sudut permodalan, perusahaan yang memiliki porsi hutang yang lebih rendah dibanding pada modal sendiri membuat harga saham perusahaan ini bisa naik. 
Harga saham ialah nilai saat ini atas arus kas yang diperoleh oleh pemilik saham dikemudian hari. Bagi perusahaan sendiri, saham ialah hak kepemilikan atas asset perusahaan, semakin besar pendapatan harga saham, dengan demikian perusahaan itu akan baik. Kenaikan dan penurunan dari harga saham memiliki hubungan keterkaitan dengan kenaikan dan penurunan dari nilai dari perusahaan tersebut berdasarkan pada pasar pada umumnya. Di dalam pembelajaran makro ekonomi, harga saham dapat dijadikan sebagai indikator keadaan ekonomi dari Negara yang berkaitan serta keadaan industri yang dijalani.

Tabel 1. Perkembangan Laba Bersih Setlah Pajak, Total Asset, Total Hutang dan Harga Saham Perusahaan Sub sektor Perhotelan, Restoran dan Pariwisata Tahun 20142018

\begin{tabular}{crrrrr}
\hline $\begin{array}{c}\text { Kode } \\
\text { Perusahaan }\end{array}$ & Tahun & $\begin{array}{c}\text { Laba Bersih } \\
\text { Setelah Pajak }\end{array}$ & \multicolumn{1}{c}{ Total Asset } & Total Hutang & $\begin{array}{r}\text { Harga } \\
\text { Saham }\end{array}$ \\
\hline INPP & 2014 & 67.274 .944 .072 & 2.162 .633 .810 & 1.079 .816 .086 .618 & 204 \\
& 2015 & 112.287 .513 .857 & 2.310 .536 .370 & 3.952 .021 .733 .826 & 358 \\
& 2016 & 181.566 .742 .860 & 2.577 .819 .573 & 4.088 .946 .249 .808 & 565 \\
& 2017 & 147.427 .151 .843 & 2.749 .422 .391 & 4.234 .934 .266 .288 & 650 \\
FAST & 2018 & 122.894 .269 .254 & 2.989 .693 .223 & 4.356 .360 .169 .913 & 700 \\
& 2014 & 152.046 .069 & 1.982 .734 .525 .885 & 1.193 .163 .687 & 2.100 \\
& 2015 & 105.023 .728 & 4.901 .062 .529 .658 & 1.114 .917 .330 & 1.150 \\
& 2016 & 172.605 .540 & 5.155 .753 .396 .983 & 1.223 .210 .987 & 1.500 \\
\hline \multirow{3}{*}{ MAMI } & 2017 & 166.998 .578 & 6.667 .921 .476 .644 & 1.293 .570 .812 & 1.440 \\
& 2018 & 212.011 .156 & 6.964 .734 .840 .779 & 1.540 .493 .643 & 1.670 \\
& 2015 & 3.430 .996 .484 & 762.521 .218 .182 & 595.463 .637 .593 & 50 \\
& 2016 & 19.255 .029 .532 & 829.216 .584 .975 & 618.154 .817 .923 & 50 \\
& 2017 & 21.753 .416 .542 & 883.810 .096 .621 & 647.556 .051 .934 & 92 \\
& 2018 & 6.041 .141 .721 & 1.002 .602 .501 .302 & 653.909 .988 .488 & 120 \\
\hline
\end{tabular}

Sumber: Output SPSS 20

Berdasarkan pada tabel 1.1 yang dilampirkan tersebut menunjukan laba bersih setelah pajak pada perusahaan PT Indonesian Paradise Property Tbk mulai tahun 2014 menuju 2015 terjadi peningkatan dimana laba bersih tahun berjalan pada tahun 2014 sebesar Rp.67.274.944.072 naik menjadi Rp.112.287.513.857 pada 2015. Hal ini diikutin dengan peningkatan dari harga saham yang di tahun 2014 senilai Rp.204 naik jadi Rp.358 di tahun 2015. Untuk total aset pada PT Fast Food Indonesia Tbk mulai tahun 2015 menuju tahun 2016 terjadi peningkatan dimana total aset di tahun 2015 senilai Rp.4.901.062.529.658 naik menjadi Rp.5.155.753.396.983. hal ini diikutin dengan kenaikan harga saham pada 2015 sebesar Rp.1.150 naik menjadi Rp.1500. sedangkan total hutang pada PT Mas Murni Indonesia Tbk mulai tahun 2017 sampai tahun 2018 mengalami kenaikan dimana total hutang pada tahun 2017 sebesar Rp. 647.556.051.934 naik menjai Rp. 653.909.988.488 pada tahun 2018. Hail ini ikutin dengan peningkatan harga saham, dimana pada tahun 2017 senilai Rp.92 naik menjadi Rp.120. 


\section{Rumusan Masalah}

1. Bagaimanakah pengaruh dari Return On Equity pada Harga Saham yang ada di dalam Perusahaan Sub sektor Perhotelan, Restoran, dan Pariwisata yang terdaftarkan dalam Bursa Efek Indonesia untuk periode tahun 2014 sampai dengan 2018?

2. Bagaimana pengaruh Ukuran Perusahaan pada Harga Saham yang ada di dalam Perusahaan Sub sektor Perhotelan, Restoran, dan Pariwisata yang terdaftarkan dalam Bursa Efek Indonesia untuk periode tahun 2014 sampai dengan 2018?

3. Bagaimana pengaruh Debt to Equity Ratio pada Harga Saham yang ada di dalam Perusahaan Sub sektor Perhotelan, Restoran, dan Pariwisata yang terdaftarkan dalam Bursa Efek Indonesia untuk periode tahun 2014 sampai dengan 2018?

4. Bagaimana pengaruh Return on Equity, Ukuran Perusahaan, dan Debt to Equity Ratio pada Harga Saham yang ada di dalam Perusahaan Sub sektor Perhotelan, Restoran, dan Pariwisata yang terdaftarkan dalam Bursa Efek Indonesia untuk periode tahun 2014 sampai dengan 2018?

\section{Penelitian Terdahulu}

1. Hasil dari penelitian yang dilaksanakan oleh Arifin (2013), Putri dan Hernawati (2013) dalam Nugraha \& Sudaryanto (2016) memperlihatkan bahwa return on equity (ROE) memberikan sumbangan pengaruh yang positif pada harga saham. Setiap peningkatan ROE juga akan diikuti oleh peningkatan harga saham.

2. Hasil dari penelitian yang dilaksanakan Viandita (2013) secara simultan menunjukkan bahwa rasio keuangan DR, PER, EPS, dan SIZE memberikan sumbangan pengaruh signifikan pada harga saham pada perusahaan industri yang terdaftarkan dalam BEI.

3. Hasil dari penelitian yang dilaksanakan oleh wathi (2006) dalam Zaki, dkk (2017) secara parsial menjelaskan bahwa variabel Debt to Equity Ratio (DER) memberikan sumbangan pengaruh signifikan pada harga saham.

4. Hasil dari penelitian yang dilaksanakan oleh Ratih (2013) secara parsial menyatakan bahwa DER memberikan sumbangan pengaruh negatif dan signifikan pada harga saham, sedangkan untuk ROE memberikan sumbangan pengaruh positif dan signifikan pada harga saham.

\section{TINJAUAN PUSTAKA}

\section{Teori Pengaruh Return On Equity Terhadap Harga Saham}

Merujuk pada uraian penjelasan yang dinyatakan oleh Kodrat (2010:283) menjelaskan bahwa hubungan nilai intriksik atau harga saham pada return on equity (ROE) ialah positif, yakni bilamana hasil yang dihasilkan oleh equity tinggi, dengan demikian harga saham juga akan tinggi.

Merujuk pada uraian penjelasan yang dinyatakan oleh Houstan (2010:133) menjelaskan bahwa ROE yang besar biasanya mempunyai hubungan korelasi yang positif pada tingginya harga saham, sementara itu berdasarkan uraian penjelasan oleh Utari,dkk (2014) menjelaskan bahwa rasio yang tinggi akan menyebabkan membaiknya juga, hal ini menyedikan tingkatan pengembalian yang lebih tinggi kepada para pemegang dari saham. 


\section{Teori Pengaruh Ukuran Perusahaan Terhadap Harga Saham}

Merujuk pada uraian penjelasan yang dinyatakan oleh Sitanggang (2013:76) menjelaskan bahwa hasil dari penjualan yang tinggi atau kapitalisasi pasar memperlihatkan hasil prestasi yang dimiliki oleh perusahaan. Perusahaan besar memungkinkan untuk memperoleh jalan menuju sumber dana guna mendapatkan modal tambahan dengan hutang.

Merujuk pada uraian penjelasan yang dinyatakan oleh Sjahrial (2009:205) menjelaskan bahwa ukuran perusahaan, perusahaan besar yang telah kuat akan memudahkan dalam menghasilkan modal yang ada pada pasar modal diperbandingkan pada perusahaan yang tidak besar. Hal semacam ini memberikan akses kemudahan yang mana bahwa perusahaan besar mempunyai keluesan yang tinggi.

Merujuk pada uraian penjelasan yang dinyatakan oleh Riyanto (2009:304) bilamana perusahaan tersebut besar, maka semakin besar juga kedudukan perusahaan tersebut di dalam pasar modal ataupun pasar uang, dengan demikian sekuritas pasar menjadi baik, dan dalam memperoleh modal dengan biaya yang rendah ialah tinggi.

\section{Teori Pengaruh Debt to Equity Ratio Terhadap Harga saham}

Merujuk pada uraian penjelasan yang dinyatakan oleh Weston dan Thomas (2011:53) menjelaskan bahwa kenaikan kebangkrutan sebagai dampak dari leverage akan mengakibatkan penurunan pada nilai perusahaan.

Merujuk pada uraian penjelasan yang dinyatakan oleh Kamaludin dan Indriani (2012:314) menjelaskan bahwa nilai perusahaan akan mengalami penurunan yang disebabkan oleh penggunaan dari utang yang berlebihan dan sangat tinggi.

Merujuk pada uraian penjelasan yang dinyatakan oleh Sartono (2010:257) menjelaskan bahwa bilamana nilai dari perusahaan yang mempergunakan hutang tersebut lebih tinggi dibanding pada nilai dari perusahaan yang tidak mempergunakan hutang. Pengaruh dari transaksi semacam ini pastinya menyebabkan harga saham dari perusahaan yang mempunyai hutang akan mengalami penurunan, sementara itu harga saham yang tidak mempunyai hutang akan mengalami kenaikan.

\section{KERANGKA KONSEPTUAL}

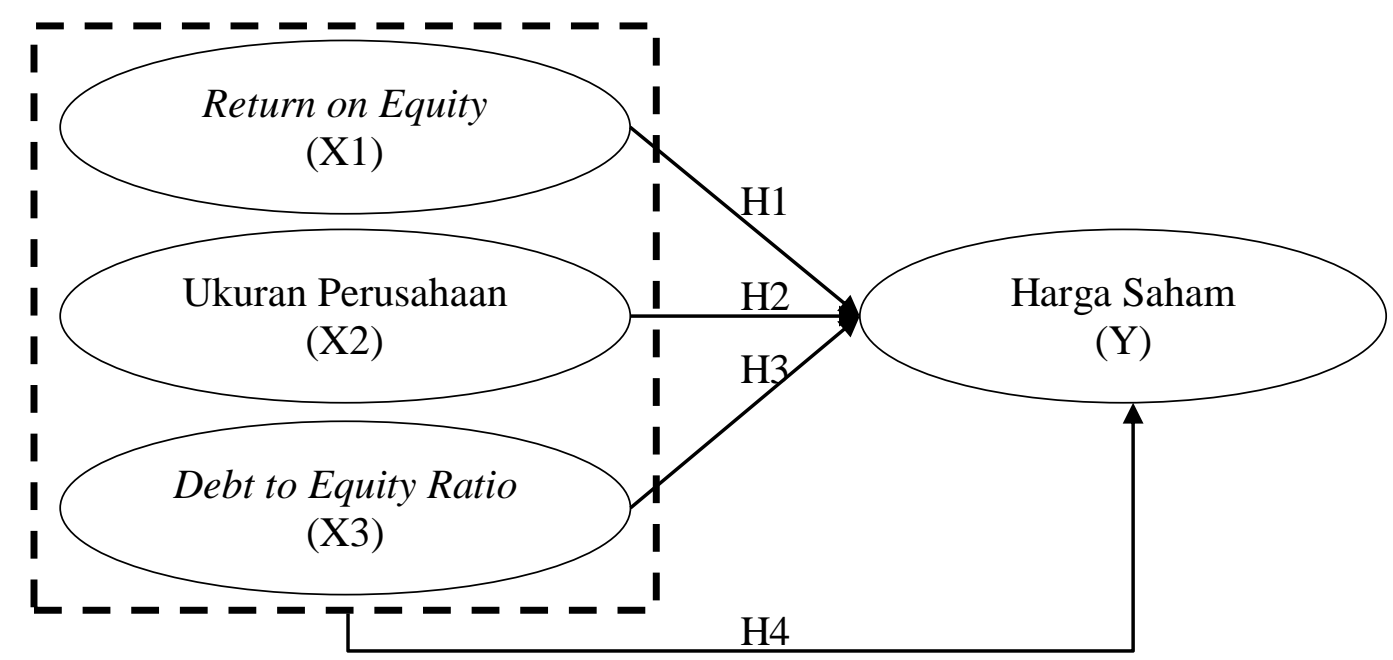

Gambar 1. Kerangka Konseptual 


\section{Hipotesis Penelitian}

Berdasarkan kerangka konseptual, maka hipotesis dari penelitian ini ialah sebagaimana berikut ini:

H1: Return on Equity memberikan sumbangan pengaruh pada Harga Saham dari Perusahaan Sub sektor Perhotelan, Restoran, dan Pariwisata untuk periode waktu tahun 2014 sampai dengan 2018.

H2: Ukuran Perusahaan memberikan sumbangan pengaruh pada Harga Saham dari Perusahaan Sub sektor Perhotelan, Restoran, dan Pariwisata untuk periode waktu tahun 2014 sampai dengan 2018.

H3: Debt to Equity Ratio memberikan sumbangan pengaruh pada Harga Saham dari Perusahaan Sub sektor Perhotelan, Restoran, dan Pariwisata untuk periode waktu tahun 2014 sampai dengan 2018.

H4: Return On Equity, Ukuran Perusahaan dan Debt to Equity Ratio memberikan sumbangan pengaruh pada Harga Saham dari Perusahaan Sub sektor Perhotelan, Restoran, dan Pariwisata untuk periode waktu tahun 2014 sampai dengan 2018.

\section{METODOLOGI PENELITIAN}

\section{Metode Penelitian}

\section{Tempat dan Waktu Penelitian}

Penelitian ini dilaksanakan dengan cara melaksanakan pengambilan data pada perusahaan untuk sub sektor perdagangan jasa dan investasi yang terdapat pada website Bursa Efek Indonesia (BEI). Data di ambil pada bulan Januari - Februari 2018.

\section{Metode Penelitian}

Dalam pelaksanaan penelitian ini mempergunakan metode penelitian kuantitatif. Data sekunder adalah data yang dipergunakan di dalam pelaksanaan penelitian ini yakni laporan yang dilaksanakan pemublikasian pada Bursa Efek Indonesia. Sumber data yang diperoleh ialah dengan mempergunakan studi dokumentasi. Jenis penelitian yang dipergunakan ialah deskriptif kuantitatif, dan sedangkan sifat dari penelitian ialah dengan mempergunakan eksplanatory.

\section{Populasi}

Di dalam pelaksanaan penelitian ini, populasi yang dipergunakan ialah Perusahaan Perdagangan, Jasa, dan Investasi yang terdaftarkan pada Bursa Efek Indonesia untuk periode tahun 2014 sampai dengan 2018 yang jumlahnya ialah 129 unit perusahaan. Merujuk pada uraian penjelasan yang dikemukakan oleh Sugiyono (2017:80) mengemukakan bahwa populasi ialah suatu wilayah yang digeneralisasikan berdasarkan atas obyek dan juga subyek yang memiliki karakteristik serta juga kualitas khusus yang ditentukan oleh peneliti untuk dapat dijadikan sebagai pelajaran dan lalu dilaksanakan penarikan suatu kesimpulan.

\section{Sampel}

Berdasarkan pada uraian yang diungkapkan oleh Sugiyono (2017:81) mengungkapkan bahwa sampel ialah parsial atau sebagian dari jumlah serta ciri khas tertentu yang dipunyai 
atau yang terdapat pada populasi itu sendiri. Metode pengambilan sampel dipilih dengan mempergunakan metode purposive sampling, yakni pengambilan terhadap sampel penelitian yang dilandaskan terhadap ciri khas.

Tabel 2. Sampel Penelitian

\begin{tabular}{|c|c|c|}
\hline No & Kriteria & $\begin{array}{l}\text { Jumlah } \\
\text { Sampel }\end{array}$ \\
\hline 2 & $\begin{array}{l}\text { Perusahaan sub-sektor pariwisata, restoran serta hotel yang terdaftarkan } \\
\text { pada Bursa Efek Indonesia untuk periode tahun } 2014 \text { sampai dengan } 2018 . \\
\text { Perusahaan sub-sektor pariwisata, restoran serta hotel yang terdaftarkan } \\
\text { pada Bursa Efek Indonesia yang tidak melaksanakan publikasi } \\
\text { laporan keuangan untuk periode tahun } 2014 \text { sampai dengan } 2018 \text {. }\end{array}$ & $(10)$ \\
\hline 3 & $\begin{array}{l}\text { Perusahaan sub-sektor pariwisata, restoran serta hotel yang terdaftarkan } \\
\text { pada Bursa Efek Indonesia yang tidak melaksanakan publikasi harga saham } \\
\text { secara runtut dan lengkap untuk periode tahun } 2014 \text { sampai dengan } 2018 \text {. } \\
\text { Perusahaan sub-sektor pariwisata, restoran serta hotel yang terdaftarkan } \\
\text { pada Bursa Efek Indonesia yang mempunyai laba negatif untuk } \\
\text { periode tahun } 2014 \text { sampai dengan } 2018 \text {. }\end{array}$ & (7) \\
\hline \multicolumn{2}{|r|}{ Total dari perusahaan yang memenuhi kriteria dari sampel } & 14 \\
\hline \multicolumn{2}{|r|}{ Tahun pengamatan } & 5 \\
\hline \multicolumn{2}{|c|}{ Total sampel selama periode berjalan $(14 \times 5)$} & 70 \\
\hline
\end{tabular}

\section{Teknik Pengumpulan Data}

Di dalam pelaksanaan penelitian ini, teknik dari pengumpulan data yang didapatkan ialah dengan cara melaksanakan studi dokumentasi. Berdasarkan pada uraian penjelasan yang dikemukakan oleh Sugiyono (2017:240) menjelaskan bahwa dokumentasi ialah suatu pengumpulan data yang dilaksanakan dengan cara memahami dokumen baik yang berbentuk karya. Gambar atau tulisan nonomental dari seseorang.

Peneliti melaksanakan pengumpulan beberapa data yang koheren berdasarkan pada sumber data yang berasal dari informasi, jurnal dan juga buku. Studi dokumentasi yang didapatkan oleh peneliti ialah laporan keuangan yang terdapat pada investasi, perdagangan dan jasa yang terdaftarkan pada bursa efek Indonesia.

\section{Definisi Operasional Variabel}

Di dalam pelaksanaan penelitian ini, variabel yang dipergunakan ialah berpa tiga variabel bebas atau independen dengan variabel terikat atau dependen, diantaranya ialah:

\section{Variabel Return On Equity}

Menurut Darmadji dan Fakhruddin (2015:64) menjelaskan bahwa Return On Equity ialah suatu rasio keuangan yang massif dipergunakan untuk melaksanakan pengukuran pada kinerja yang diraih oleh suatu perusahaan atau organisasi. Berdasarkan pada uraian penjelasan yang dikemukakan oleh Kasmir (2012:204) menjelaskan bahwa formula yang dipergunakan untuk menentukan Return On Equity (ROE) ialah sebagaimana berikut ini: 
2. Variabel Ukuran Perusahaan

$$
\mathrm{ROE}=\frac{\text { laba Setelah Pajak }}{\text { Equity }}
$$

Menurut Ali dan Rodoni (2014:193) menjelaskan bahwa ukuran Perusahaan adalah data kontrol yang umum untuk dipakai guna orientasi terdapatnya data yang ada pada objek yang sedang dilaksanakan penelitian yang mempunyai ciri khas tertentu atau perbedaan ciri khas khusus.

Ukuran perusahaan $=\mathrm{Ln}($ total asset $)$

\section{Variabel Debt to Equity Ratio}

Merujuk pada uraian penjelasan yang dikemukakan oleh Darmadji dan Fakhruddin (2011:158) menjelaskan bahwa rasio utang pada ekuitas (Debt to Equity Ratio) ialah suatu rasio yang dipergunakan untuk melaksanakan pengukuran mengenai seberapa jauh besaran hutang yang bisa dibayarkan dengan mempergunakan modal sendiri.

$$
\mathrm{DER}=\frac{\text { Total Debt }}{\text { Total Equity }}
$$

4. Harga Saham

Merujuk pada uraian penjelasan yang dikemukakan oleh Kodrat (2010:1) menjelaskan bahwa harga saham ialah harga yang terjadi pada bursa saham yang biasanya bahwa harga tersebut didapatkan guna melaksanakan penghitungan pada nilai saham, formula yang dipergunakan untuk menghitung harga saham ialah sebagaimana berikut ini:

$$
\text { Harga Saham }=\text { closing price }
$$

\section{Uji Asumsi Klasik}

\section{Uji Normalitas}

Merujuk pada uraian penjelasan yang dikemuakan oleh Ghozali (2016:154-156) Pengujian normalitas memiliki tujuan guna melaksanakan pengujian berkenaan dengan permodelan regresi apakah variabel residual atau pengganggu telah terdistribusi normal. Terdapat dua metode dalam melaksanakan pendeteksian berkenaan dengan apakah variabel residual atau penganggu tersebut telah terdistrisibusi secara normal, yakni dengan mempergunakan uji statistic dan analisis grafik

\section{Uji Multikolonieritas}

Merujuk pada uraian penjelasan yang dikemuakan oleh Ghozali (2016:103) menjelaskan bahwa pengujian multikolinieritas memiliki guna untuk memahami akankah di dalam permodelan regresi tersebut diketemui terdapatnya korelasi yang terjadi antar variabel independen tersebut. Multikolinieritas di dalam model regresi bisa ditinjau berdasarkan pada besarnya nilai yang ada pada VIF (Variance Inflation Factor) dan juga tolerance. bilamana nilai yang ada pada tolerance $>0,10$, sedangkan nilai dari VIF $<10$, dengan demikian tidak terdapat gejala multikolinieritas. 


\section{Uji Autokorelasi}

Merujuk pada uraian pendapat oleh Ghozali (2016:103) mengungkapkan bahwa pengujian autokolerasi memiliki kegunaan untuk melaksanakan pengujian akankah di dalam permodelan regresi yang dilaksanakan tersebut bersifat korelasi yang linear antara kesalahan pengganggu pada periode t-1 (sebelumnya).

\section{Uji Heteroskedastisitas}

Merujuk pada uraian pendapat oleh Ghozali (2016:134) menjelaskan bahwa heteroskedastitas dilaksanakan dengan mempergunakan pengujian glejser untuk meregresikan nilai dari absolute residual. Bilamana nilaianya 0.05 , dengan demikian bisa dinyatakan bebas dari asumsi heteroskedastitas, sebaliknya bilamana nilai dari Sig lebih rendah dibanding pada 0.05 , dengan demikian berlangsung sifat asumsi heteroskedastitas

\section{Model Analisis Data Penelitian}

Model Penelitian

Merujuk pada uraian pendapat oleh Ghozali (2016 : 94) mengungkapkan bahwa fungsi dari pelaksanaan penganalisisan regresi ialah agar memahami besaran dari pengaruh yang diprediksikan dari variabel bebas (X) pada variabel terikat atau dependen (Y). Merujuk pada uraian pendapat oleh Ghozali (2016 : 94) menjelaskan bahwa secara sistematis, bentuk umum dari persamaan permodelan regresi liniear berganda ialah seperti yang diungkapkan di bawah ini:

$$
\mathrm{Y}=\mathrm{a}+\mathrm{b}_{1} \mathrm{X}_{1}+\mathrm{b}_{2} \mathrm{X}_{2}-\mathrm{b}_{3} \mathrm{X}_{3}+\mathrm{e}
$$

Keterangan:

\begin{tabular}{|c|c|c|c|}
\hline Y & = Harga Saham & $\mathrm{a}$ & $=$ Konstanta \\
\hline b1b2b3 & $=$ koefisien regresi & $\mathrm{X} 1$ & $=$ Return on Equity \\
\hline $\mathrm{X} 2$ & $\begin{array}{l}=\text { Ukuran Perusahaan } \\
=\text { tinokat kesalahan } 5 \%\end{array}$ & $\mathrm{X} 3$ & $=$ Debt to Equity Ratio \\
\hline
\end{tabular}

Koefisien Determinasi

Merujuk pada uraian pendapat oleh Ghozali (2016:95) menjelaskan bahwa Koefisien Determinasi $\left(\mathrm{R}^{2}\right)$ sering diartikan besaran kapasitas atau kemampuan yang ada pada keseluruhan variabel bebas atau independen dalam memperjelaskan atau memprediksikan pada variabel terikat atau dependen dengan cara mengkuadratkan koefisien korelasi (R). nilai dari koefisien determinasi tersebut ialah kisaran antara satu sampai nol.

\section{Pengujian Hipotesis Secara Simultan (Uji F)}

Merujuk pada uraian pendapat oleh Ghozali (2013:171) menjelaskan bahwa Pengujian hipotesis simultan (uji F) memiliki kegunaan untuk melihat apakah variabel bebas atau independen memberikan sumbangan pengaruh atau dapat memprediksi pada variabel dependen secara bersama-sama. Untuk mengetahui apakah hipotesis diajukan diterima atau ditolak dilaksanakanlah dengan melaksanakan komparasi antara nilai dari $\mathrm{F}$ hitung dengan $\mathrm{F}$ tabel dengan kriteria sebagaimana berikut ini: 
Kriteria pengujian

$\mathrm{H}_{\mathrm{a}}$ diterima bilamana $\mathrm{F}_{\text {hitung }}$ lebih tinggi dibanding $\mathrm{F}_{\text {tabel }}$ dan sedangkan untuk nilai signifikansi lebih rendah dibanding pada 0,05

$\mathrm{H}_{\mathrm{o}}$ ditolak bilamana $\mathrm{F}_{\text {hitung }}$ lebih rendah dibanding $\mathrm{F}_{\text {tabel }}$ dan sedangkan untuk untuk nilai signifikansi lebih tinggi dibanding pada 0,05 .

Menentukan Hipotesis

1. $\mathrm{H} 0: \mathrm{b} 1=\mathrm{b} 2=\mathrm{b} 3=0$

Dengan ini menjelaskan bahwa secara bersama-sama atau simultan, variabel bebas atau independen dari Return On Equity, Ukuran Perusahaan dan Firm Size tidak memberikan sumbangan pengaruh pada harga saham dari perusahaan sub-sektor pariwisata, restoran serta hotel yang terdaftarkan pada Bursa Efek Indonesia untuk periode tahun 2014 sampai dengan 2018.

2. $\mathrm{Ha}: \mathrm{b} 1 \neq \mathrm{b} 2 \neq \mathrm{b} 3 \neq 0$

Dengan ini menjelaskan bahwa secara bersama-sama atau simultan, variabel bebas atau independen dari Return On Equity, Ukuran Perusahaan dan Firm Size memberikan sumbangan pengaruh pada harga saham dari perusahaan sub-sektor pariwisata, restoran serta hotel yang terdaftarkan pada Bursa Efek Indonesia untuk periode tahun 2014 sampai dengan 2018.

\section{Pengujian Hipotesis Secara Parsial (Uji t)}

Merujuk pada uraian pendapat yang dikemukakan oleh Ghozali (2016:97) menjelaskan bahwa pengujian statistif $t$ intinya ialah untuk memperlihatkan seberapa besar pengaruh secara parsial dari variabel bebas atau independen dalam menerangkan atau memprediksi variasi dari variabel terikat atau dependen dengan hipotesis nol $\left(\mathrm{H}_{0}\right)$ yang akan dilaksanakan pengujian apakah nilai parameter $\left(b_{i}\right)$ nilainya ialah nol dan untuk mengetahui apakah hipotesis diajukan diterima atau ditolak dilaksanakanlah dengan melaksanakan komparasi antara nilai dari $\mathrm{F}$ hitung dengan $\mathrm{F}$ tabel dengan kriteria sebagaimana berikut ini:

Kriteria pengujian

1. $\mathrm{H}_{0}$ : ditolak bilamana nilai dari signifikansi dari $\mathrm{t}_{\text {hitung }}$ lebih kecil dibanding pada nilai dari alpha.

2. $\mathrm{H}_{0}$ : diterima bilamana nilai dari signifikansi dari $\mathrm{t}_{\text {hitung }}$ lebih besar dibanding pada nilai dari alpha.

Menentukan Hipotesis

1. $\mathrm{H}_{0}=\mathrm{b}_{1}=\mathrm{b}_{2}=\mathrm{b}_{3}=0$

Dengan ini menjelaskan bahwa secara bagian atau parsial, variabel bebas atau independen dari Return On Equity, Ukuran Perusahaan dan Firm Size memberikan sumbangan pengaruh pada harga saham dari perusahaan sub-sektor pariwisata, restoran serta hotel yang terdaftarkan pada Bursa Efek Indonesia untuk periode tahun 2014 sampai dengan 2018

2. $\mathrm{H}_{\mathrm{a}}: \mathrm{b}_{1} \neq \mathrm{b}_{2} \neq \mathrm{b}_{3} \neq 0$ 
Dengan ini menjelaskan bahwa secara bagian atau parsial, variabel bebas atau independen dari Return On Equity, Ukuran Perusahaan dan Firm Size tidak memberikan sumbangan pengaruh pada harga saham dari perusahaan sub-sektor pariwisata, restoran serta hotel yang terdaftarkan pada Bursa Efek Indonesia untuk periode tahun 2014 sampai dengan 2018

\section{HASIL PENELITIAN DAN PEMBAHASAN}

\section{Hasil Penelitian Statistik Deskriptif}

Di bawah ini ialah statistif deskriptif yang bisa berupa jawaban dari standar deviasi, rata-rata, maksimum dan minimum dari responden, hal ini bisa ditinjau berdasarkan pada tabel sebagaimana di bawah ini

Tabel 3. Hasil Uji Descriptive Statistics

\begin{tabular}{lrrrrr}
\hline & N & Minimum & Maximum & Mean & Std. Deviation \\
\hline LN_ROE & 70 & $-7,8925$ & $-1,8213$ & $-3,304757$ & 1,2909659 \\
LN_UKURAN & & & & & \\
PERUSAHAAN & 70 & 3,0678 & 3,4175 & 3,271856 &, 0993784 \\
LN_DER & 70 & $-1,9822$ &, 6682 &,- 654164 &, 6219569 \\
LN_HARGA SAHAM & 70 & 3,9120 & 8,3664 & 6,296270 & 1,0821563 \\
Valid N (listwise) & 70 & & & & \\
\hline
\end{tabular}

Sumber: Output SPSS 20

Merujuk pada lampiran dari tabel 3.1 yang dilampirkan tersebut di atas, dengan demikian bisa dilihat bahwa standar deviasi, nilai rata-rata (Mean), nilai maksimum, serta nilai minimum dari Return On Equity (X1), Ukuran Perusahaan (X2), Debt To Equity Ratio (X3) dan Harga Saham (Y) ialah sebagaimana berikut ini:

1. Variabel bebas atau independen dari Return On Equity $\left(\mathrm{X}_{1}\right)$ dengan sampel ialah sejumlah 70 memiliki nilai minimum $-7,8925$ dan nilai maksimum ialah senilai $-1,8213$, sementara itu untuk nilai rata-rata (Mean) -3,304757 dan untuk standar deviasi ialah senilai 1,2909659 .

2. Variabel bebas atau independen dari Ukuran Perusahaan $\left(\mathrm{X}_{2}\right)$ dengan sampel ialah sejumlah 70 memiliki nilai minimum 3,0678 dan nilai maksimum ialah senilai 3,4175, sementara itu untuk nilai rata-rata (Mean) 3,271856 dan untuk standar deviasi ialah senilai 0,0993784.

3. Variabel bebas atau independen dari Debt To Equity Ratio $\left(\mathrm{X}_{3}\right)$ dengan sampel ialah sejumlah 70 memiliki nilai minimum $-1,9822$ dan nilai maksimum ialah senilai 0,6682 , sementara itu untuk nilai rata-rata (Mean) -0,654164 dan untuk standar deviasi ialah senilai 0,6219569 .

4. Variabel bebas atau independen dari Harga Saham (Y) dengan sampel ialah sejumlah 70 memiliki nilai minimum 3,9120 dan nilai maksimum ialah senilai 8,3664, sementara itu untuk nilai rata-rata (Mean) 6,296270 dan untuk standar deviasi ialah senilai 1,0821563. 


\section{Uji Asumsi Klasik}

\section{Uji Normalitas}

Pengujian normalitas dipergunakan untuk melaksanakan pengujian akankah residual yang ada pada persamaan regresi tersebut mempunyai terdistrisibusi tidak normal atau normal. Pengujian ini dilaksanakan dengan cara melaksanakan pendeteksian dengan mempergunakan analisis statistic dan juga analisis grafik.

\section{Analisi Grafik}

a. Grafik Histogram

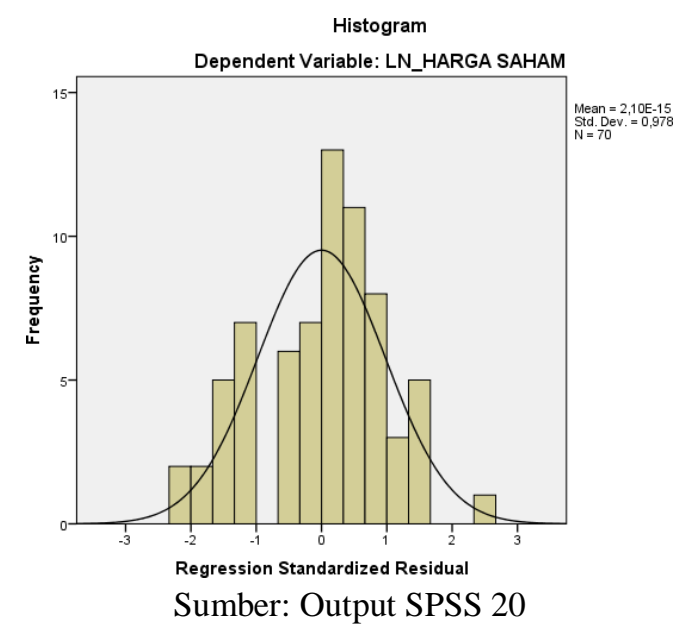

\section{Gambar 2. Hasil Uji Grafik Histogram}

Grafik histogram yang tertera di dalam gambar tersebut di atas, dapat diketahui bahwa distribusi data mempunyai kurva yang bentuknya lonceng, yang mana distribusi data tersebut tidak melenceng ke kanan ataupun melenceng ke kiri. Hal semacam ini memperlihatkan bahwa data telah terdistribusi secara normal

b. Normal Probability Plot

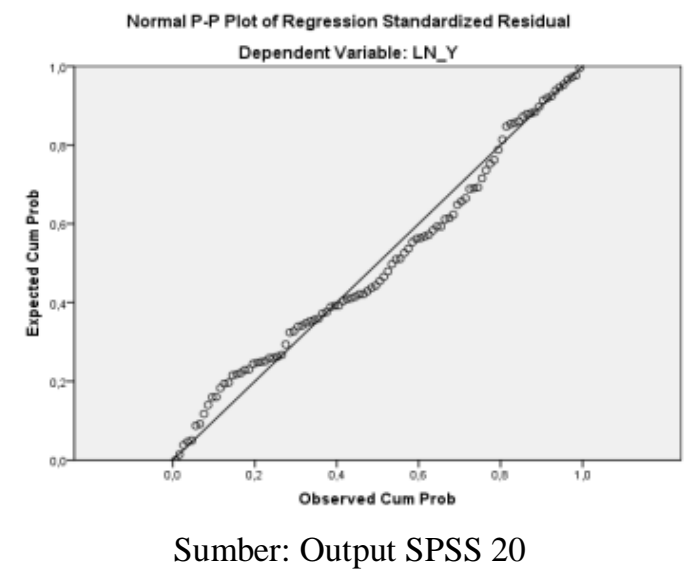

Gambar 3. Hasil Uji Probability Plot

Berdasarkan pada gambar tersebut di atas, Normal P.P Plot of Regression Standardized Residual yang disajikan tersebut di atas memperlihatkan titik menyebar di sekitar diagonal dan penyebaran dari titik-titik tersebut mengikuti pada arah dari 
garis diagonal dengan demikian bisa dihasilkan suatu simpulan bahwa data model dari regresi tersebut memiliki distribusi yang normal

\section{Uji Statistik}

Pelaksanaan pengujian normalitas dari statistik tersebut bisa dilaksanakan dengan mempergunakan pengujian statistic non-parametik kolmogorov-smirnov (K-S), ketentuan dalam pengambilan ketentuan berkenaan dengan data yang memiliki distribusi normal ialah dengan memperhatikan kaidah sebagaimana berikut ini:

a. Bilamana nilai dari signifikansi tersebut lebih rendah dibanding pada 0.05 , dengan demikian data residual tersebut mempunyai distribusi yang tidak normal

b. Bilamana nilai dari signifikansi tersebut lebih tinggi dibanding pada 0.05 , dengan demikian data residual tersebut mempunyai distribusi yang normal

Tabel 4. Hasil Uji Normalitas dengan Kolomogorov-Smirnov

One-Sample Kolmogorov-Smirnov Test

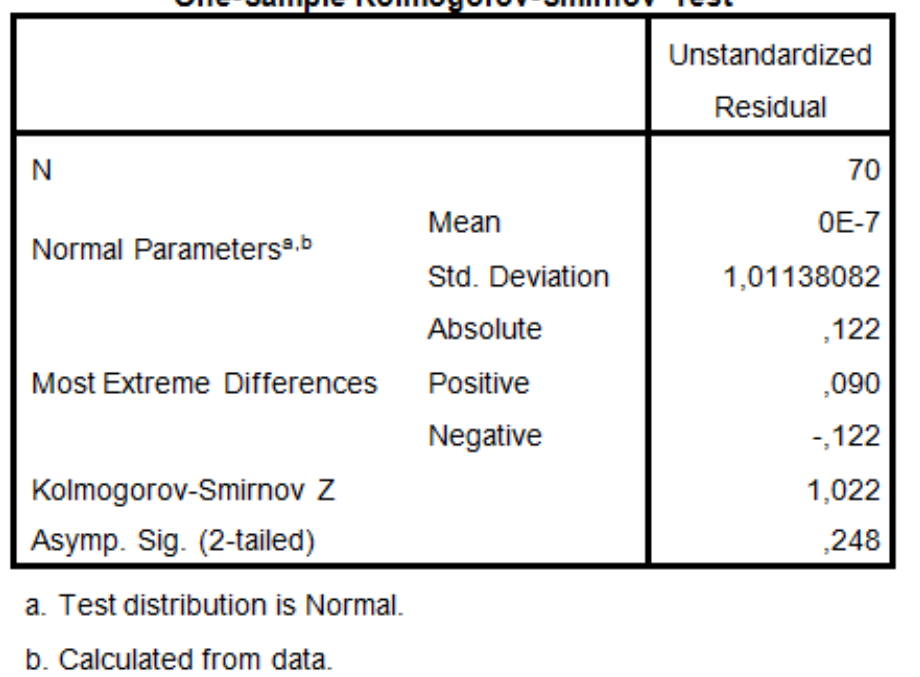

Sumber: Output SPSS 20

Dari hasil di atas kita lihat pada kolom Kolmogorov-Smirnov dan dapat diketahui bahwa nilai Asymp. Sig. (2-tailed) pada data sesudah ditranformasi sebesar 0,248. Dimana nilai Asymp. Sig. (2-tailed) > nilai signifikan 0,05 sehingga data tersebut disimpulkan data terdistribusi normal.

Merujuk pada tabel yang disajikan tersebut di atas, hasil dari pengujian normalitas dengan mempergunakan nilai Asymp. Sig. (2-tailed) memperlihatkan bahwa nilai dari signifikannya ialah senilai 0,248>0,05, dengan demikian hasil dari nilai Asymp. Sig. (2-tailed) memperlihatkan bahwa data tersebut memiliki distribusi yang normal

\section{Uji Heteroskedastisitas}

Pengujian heteroskedastisitas memiliki tujuan untuk mengetahui bahwa di dalam permodelan regresi tersebut apakah terdapat ketidaksamaan variabel yang terdapat pada residual dari suatu pengamatan ke pengamatan yang lain. Hasil uji heteroskedastisitas dapat dilihat pada grafik di bawah ini: Grafik Scatterplot 


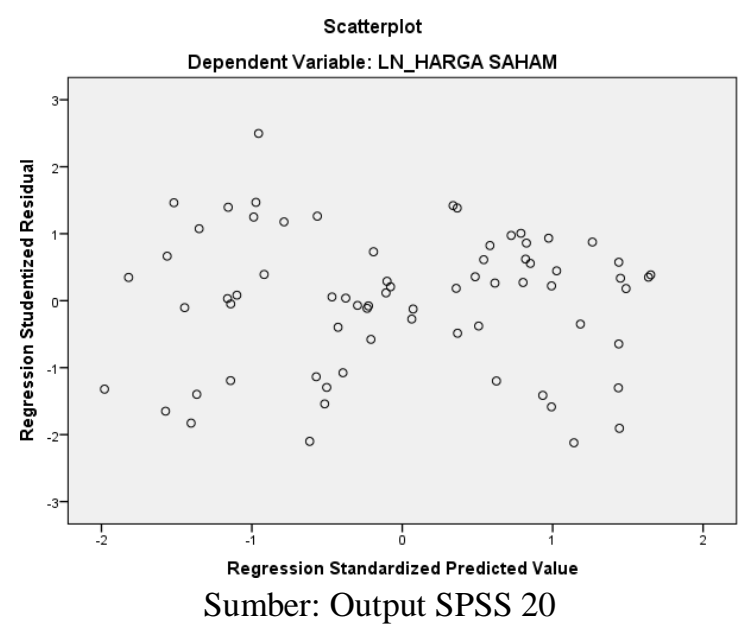

Gambar 5. Hasil uji Grafik Scatterplot

Dari output di atas dapat diketahui bahwa menyebar di atas dan di bawah angka 0 pada sumbu Y. Jadi dapat disimpulkan bahwa tidak terjadi masalah heteroskedastisitas dalam model regresi.

Berdasarkan pada grafik yang disajikan tersebut di atas bisa ditinjau bahwa data tersebut sifatnya menyebar dengan tidak beraturan, sehingga tidak menghasilkan sebuah pola serta menjauhi titik 0 , maka data tersebut dinyatakan terbebas dari heteroskedastisitas

\section{Uji Glejser}

Tabel 5. Hasil Uji Glejser

Coefficients $^{\mathrm{a}}$

\begin{tabular}{lrrrrr}
\hline Model & \multicolumn{2}{c}{$\begin{array}{c}\text { Unstandardized } \\
\text { Coefficients }\end{array}$} & $\begin{array}{c}\text { Standardized } \\
\text { Coefficients }\end{array}$ & t & \multirow{2}{*}{ Sig. } \\
\cline { 2 - 4 } & \multicolumn{1}{c}{ B } & Std. Error & Beta & & \\
\hline (Constant) & $-2,967$ & 2,399 & & $-1,237$ &, 221 \\
LN_ROE &,- 087 &, 060 &,- 185 & $-1,452$ &, 151 \\
LN_UKURAN PERUSAHAAN & 1,072 &, 741 &, 174 & 1,447 &, 153 \\
LN_DER &, 043 &, 123 &, 044 &, 349 &, 729 \\
\hline
\end{tabular}

a. Dependent Variable: LN_RES2

Sumber: Output SPSS 20

Berdasarkan pada tabel yang disajikan tersebut di atas menunjukan bahwa nilai signifikansi dari yang ada pada variabel bebas atau independen, yakni Return on Equity ialah senilai 0,151>0,05, variabel bebas atau independen dari Ukuran Perusahaan ialah senilai 0,153>0,05, variabel bebas atau independen dari Debt to Equity Ratio ialah senilai 0,729. Oleh karena itu, hasil dari pengujian Glejser tidak terdapat permasalahan yang berkenaan dengan heteroskedastisitas

\section{Uji Multikolinearitas}

Pengujian multikolonieritas dilaksanakan untuk melaksanakan pengujian akankah data yang dipergunakan tersebut terdapat hubungan korelasi diantara variabel bebas atau independen. Pada umumnya, nilai yang dipergunakan untuk memperlihatkan sifat multikolinearitas ialah nilai VIF lebih kecil dibanding 10 atau nilai tolerance besar dari 0.10 
Tabel 6. Hasil Pengujian Multikolinearitas

Coefficients $^{\mathbf{a}}$

\begin{tabular}{|c|c|c|c|c|c|c|c|}
\hline \multirow[t]{2}{*}{ Model } & \multicolumn{2}{|c|}{$\begin{array}{l}\text { Unstandardized } \\
\text { Coefficients }\end{array}$} & \multirow{2}{*}{$\begin{array}{r}\begin{array}{r}\text { Standardized } \\
\text { Coefficients }\end{array} \\
\text { Beta }\end{array}$} & \multirow[t]{2}{*}{$\mathrm{t}$} & \multirow[t]{2}{*}{ Sig. } & \multicolumn{2}{|c|}{$\begin{array}{l}\text { Collinearity } \\
\text { Statistics }\end{array}$} \\
\hline & $\mathrm{B}$ & $\begin{array}{l}\text { Std. } \\
\text { Error }\end{array}$ & & & & Tolerance & VIF \\
\hline (Constant) & 9,003 & 4,120 & & 2,185 & ,032 & & \\
\hline LN_ROE & 128 & , 103 & 153 & 1,237 & 220 & 871 & 1,148 \\
\hline $\begin{array}{l}\text { LN_UKURAN } \\
\text { PERUSAHAAN }\end{array}$ &,- 607 & 1,272 &,- 056 &,- 477 & ,635 & ,970 & 1,031 \\
\hline LN_DER & ,456 &, 212 & ,262 & 2,151 & ,035 & ,892 & 1,121 \\
\hline
\end{tabular}

Sumber: Output SPSS 20

Merujuk pada hasil multikolinearitas yang terlampir pada tabel tersebut di atas, dengan demikian memperlihatkan bahwa nilai dari VIF untuk keseluruhan variabel bebas lebih rendah dibanding pada 10, sedangkan untuk nilai dari tolerance lebih tinggi dibanding pada 0.10. oleh sebab itu, keseluruhan variabel penelitian yang dimasukkan di dalam penelitian tidak terdapat sifat multikolinearitas atau telah memiliki distrisibusi normal

\section{Uji Autokorelasi}

Tujuan dari pengujian autokorelasi ialah untuk menunjukkan apakah di dalam permodelan regresi yang dilakukakn tersebut terdapat korelasi (keterkaitan hubungan) yang terjadi antara kesalahan pengganggu pada periode $t$ dengan $t-1$. Model regresi yang baik adalah regresi yang bebas dari autokorelasi. Kriteria untuk melihat uji ini yaitu du $<$ dw $<4$ du sebagaimana pada tabel 7 berikut ini:

Tabel 7. Hasil Uji Autokorelasi

\begin{tabular}{l|r|r|r|r|r|}
\hline Model & $R$ & R Square & $\begin{array}{c}\text { Adjusted R } \\
\text { Square }\end{array}$ & $\begin{array}{c}\text { Std. Error of the } \\
\text { Estimate }\end{array}$ & Durbin-Watson \\
\hline 1 &, $356^{\mathrm{a}}$ &, 127 &, 087 & 1,0341113 & 1,860 \\
\hline
\end{tabular}
a. Predictors: (Constant), LN_DER, LN_UKURAN PERUSAHAAN, LN_ROE
b. Dependent Variable: LN_HARGA SAHAM
Sumber: Output SPSS 20

Merujuk pada hasil dari pengujian autokorelasi yang dilampirkan pada tabel tersebut di atas, bisa ditinjau bahwa nilai dari Durbin-Watson ialah 1,860. Berdasarkan pada hasil dari Durbin Watson tersebut di atas, bisa dihasilkan nilai dari du ialah $\mathrm{du}<\mathrm{dw}<4$-du $(.7028<1,860<2,2972)$, dengan demikian bisa dihasilkan suatu simpulan bahwa persamaan regresi tersebut terbebas dari sifat autokorelasi

\section{Hasil Analisi Data}

Metode analisi yang digunakan adalah analisis regresi linier berganda. Pada dasarnya, analisis regresi liniar berganda ini ialah pengembangan dari analisis sederhana yakni dengan 
melaksanakan penambahan jumlah dari variabel bebas atau independen yang sebelumnya ialah hanya satu variabel bebas atau independen.

Tabel 8. Hasil Analisis Regresi Linear Berganda Coefficients $^{\mathrm{a}}$

\begin{tabular}{lrrrrr}
\hline Model & \multicolumn{2}{c}{$\begin{array}{c}\text { Unstandardized } \\
\text { Coefficients }\end{array}$} & $\begin{array}{c}\text { Standardized } \\
\text { Coefficients }\end{array}$ & t & Sig. \\
\cline { 2 - 4 } & \multicolumn{1}{c}{ B } & Std. Error & \multicolumn{1}{c}{ Beta } & & \\
\hline (Constant) & 9,003 & 4,120 & & 2,185 &, 032 \\
LN_ROE &, 128 &, 103 &, 153 & 1,237 &, 220 \\
LN_UKURAN PERUSAHAAN &,- 607 & 1,272 &,- 056 &,- 477 &, 635 \\
LN_DER &, 456 &, 212 &, 262 & 2,151 &, 035 \\
\hline
\end{tabular}

Sumber: Output SPSS 20

Persamaan regresi dari hasil data setelah ditransform sebagai berikut:

$$
\text { LN_Harga Saham }=9,003+0.128-0,607+0,456
$$

Dari tabel diatas bisa dirumuskan persamaan regresi linier berganda sebagaimana di bawah ini:

1. Nilai dari konstanta (a) ialah senilai 9,003 artinya jika variabel bebas yaitu Return On Equity (X1), Ukuran Perusahaan (X2), Debt To Equity Ratio (X3) dianggap konstan, maka nilai Harga Saham pada perusahaan sub sektor Perhotelan Restoran dan Pariwisata yang terdaftar di Bursa Efek Indonesia sebesar 9,003.

2. Koefisien regresi Return On Equity (X1) adalah 0,128. Ini menunjukkan bahwa setiap kenaikan ROE satu persen maka akan dilihat kenaikan Harga Saham sebesar 12,8 persen.

3. Koefisien regresi Ukuran Perusahaan (X2) adalah -0,607. Ini menunjukkan bahwa setiap kenaikan Ukuran Perusahaan satu persen maka akan dilihat penuruna Harga Saham sebesar 60,7 persen.

4. Koefisien regresi Debt To Equity Ratio (X3) adalah 0,456. Ini menunjukkan bahwa setiap penurunan Debt To Equity Ratio satu persen maka akan dilihat penurnan Harga Saham sebesar 45,6 persen.

\section{Koefisien Determinasi (R2)}

Nilai koefisien determinasi digunakan untuk mengukur seberapa besar pengaruh Return On Equity (X1), Ukuran Perusahaan (X2), Debt To Equity Ratio (X3) terhadap Harga Saham pada perusahaan sub sektor Perhotelan Restoran dan Pariwisata yang terdaftar di Bursa Efek Indonesia 2014-2018. Berikut ini nilai dari koefisien determinasi. 
Tabel 9. Hasil Uii Koefisien Determinasi (R2)

Model Summary

\begin{tabular}{|l|l|l|l|l|}
\hline Model & $R$ & R Square & $\begin{array}{l}\text { Adjusted R } \\
\text { Square }\end{array}$ & $\begin{array}{l}\text { Std. Error of } \\
\text { the Estimate }\end{array}$ \\
\hline 1 &, $356^{\mathrm{a}}$ &, 127 &, 087 & 1,0341113 \\
\hline
\end{tabular}

a. Predictors: (Constant), LN_DER, LN_UKURAN PERUSAHAAN, LN_ROE

Sumber: Output SPSS 20

Berdasarkan tabel diatas diperoleh nilai Adjusted $R$ Square sebesar 0,087 atau $(8,7 \%)$ Hal ini menunjukkan bahwa prosentase sumbangan pengaruh variabel independen ROE, Ukuran Perusahaan dan DER terhadap variabel dependen (Harga Saham) sebesar 8,7\%. Sedangkan sisanya sebesar $91,3 \%$ dipengaruhi atau dijelaskan oleh variabel lain yang tidak dimasukkan dalam model penelitian ini.

\section{Pengujian Hipotesis Secara Simultan (Uji-F)}

Uji hipotesis secara simultan (Uji-F) digunakan untuk mengetahui seberapa jauh pengaruh variabel independen terhadap variabel dependen secara simultan atau keseluruhan. Hasil pengujian dengan Uji-F adalah pada tabel 10 sebagai berikut.

Tabel 10. Hasil Uji F

\begin{tabular}{|rl|r|r|r|r|r|}
\hline \multicolumn{1}{|l|}{ MNOdel $^{2}$} & Sum of Squares & \multicolumn{1}{c|}{ df } & Mean Square & F & Sig. \\
\hline \multirow{2}{*}{1} & Regression & 10,224 & 3 & 3,408 & 3,187 &, $029^{\circ}$ \\
& Residual & 70,579 & 66 & 1,069 & & \\
& Total & 80,803 & 69 & & & \\
\hline
\end{tabular}

a. Dependent Variable: LN_HARGA SAHAM

b. Predictors: (Constant), LN_DER, LN_UKURAN PERUSAHAAN, LN_ROE

Sumber: Output SPSS 20

Dari tabel diatas dapat dilihat bahwa nilai Fhitung sebesar 3,187 dan dan nilai $\mathrm{F}$ tabel $\mathrm{a}=5 \%$, df 1 (jumlah variabel-1) = 2, dan df 2 (n-k-1) atau 70-3-1 = 66 (n adalah jumlah kasus dan $\mathrm{k}$ adalah jumlah variabel independen), hasil diperoleh untuk Ftabel sebesar 2.74 dan nilai sig < 0,05. Dapat disimpulkan bahwa variabel Return On Equity, Ukuran Perusahaan dan Debt To Equity Ratio secara simultan berpengaruh terhadap Harga Saham Saham pada perusahaan sub sektor Perhotelan Restoran dan Pariwisata yang terdaftar di Bursa Efek Indonesia 2014-2018

\section{Pengujian Hipotesis Secara Parsial (t)}

Uji parsial (t) pada dasarnya digunakan untuk mengetahui pengaruh masing-masing variabel independen terhadap dependen. Uji t bertujuan untuk melihat pengaruh variabel independen terhadap variabel dependen 
Tabel 11. Hasil Uji t

\begin{tabular}{lrrrrr}
\hline Model & \multicolumn{2}{c}{$\begin{array}{c}\text { Unstandardized } \\
\text { Coefficients }\end{array}$} & $\begin{array}{c}\text { Standardized } \\
\text { Coefficients }\end{array}$ & t & Sig. \\
\cline { 2 - 5 } & \multicolumn{1}{c}{ B } & Std. Error & \multicolumn{1}{c}{ Beta } & & \\
\hline (Constant) & 9,003 & 4,120 & & 2,185 &, 032 \\
LN_ROE &, 128 &, 103 &, 153 & 1,237 &, 220 \\
LN_UKURAN PERUSAHAAN &,- 607 & 1,272 &,- 056 &,- 477 &, 635 \\
LN_DER &, 456 &, 212 &, 262 & 2,151 &, 035 \\
\hline
\end{tabular}

Sumber: Output SPSS 20

Dengan pengujian 2 sisi (signifikansi $=0,025$ ) hasil diperoleh untuk t tabel sebesar 1,99656 masing-masing variabel independen secara parsial terhadap variabel dependen dapat dianalisis sebagai berikut :

1. Return On Equity (X1) mempunyai nilai thitung 1,237 dengan tingkat Signifikan 0,220. Sedangkan nilai ttabel adalah sebesar 1,99656 dengan signifikan 0,05. Sehingga kesimpulannya adalah thitung < ttabel yaitu 1,237 < 1,99656 dan nilai sig > 0,05 maka artinya variabel Return On Equity secara parsial tidak berpengaruh dan tidak signifikan terhadap terhadap Harga Saham pada perusahaan sub sektor Perhotelan Restoran dan Pariwisata yang terdaftar di Bursa Efek Indonesia 2014-2018.

2. Ukuran Perusahaan (X2) mempunyai nilai thitung -0,477 dengan tingkat Signifikan 0,635. Sedangkan nilai ttabel adalah sebesar 1,99656 dengan signifikan 0,05. Sehingga kesimpulannya adalah thitung < ttabel yaitu $-0,477<1,99656$ dan nilai sig $>0,05$ maka artinya variabel Ukuran Perusahaan secara parsial tidak berpengaruh dan tidak signifikan terhadap terhadap Harga Saham pada perusahaan sub sektor Perhotelan Restoran dan Pariwisata yang terdaftar di Bursa Efek Indonesia 2014-2018.

3. Debt To Equity Ratio (X3) mempunyai nilai thitung 2,151 dengan tingkat Signifikan 0,035. Sedangkan nilai tabel adalah sebesar 1,99656 dengan signifikan 0,05. Sehingga kesimpulannya adalah thitung < ttabel yaitu 2,151 > 1,99656 dan nilai sig < 0,05 maka artinya variabel Debt To Equity Ratio secara parsial berpengaruh dan signifikan terhadap terhadap Harga Saham pada perusahaan sub sektor Perhotelan Restoran dan Pariwisata yang terdaftar di Bursa Efek Indonesia 2014-2018.

\section{PEMBAHASAN HASIL PENELITIAN}

\section{Pengaruh Return On Equity Terhadap Harga Saham}

Berdasarkan hasil uji (t) di peroleh bahwa thitung < tabel dan nilai sig $>0,05$ sehingga Return On Equity secara parsial tidak berpengaruh dan tidak signifikan terhadap terhadap Harga Saham pada perusahaan sub sektor Perhotelan Restoran dan Pariwisata yang terdaftar di Bursa Efek Indonesia 2014-2018.

Hasil ini sejalan dengan penelitian Egam dkk, 2017 bahwa Return on Equity tidak memiliki pengaruh terhadap naik turunnya harga saham. Hal ini dapat terjadi karena rasio ini lebih ditekankan pada unsur pengukuran kinerja keuangan internal perusahaan tanpa adanya unsur eksternal dari perusahaan. Selain itu Return on Equity tidak menunjukkan kondisi yang 
sesungguhnya ketika terjadi inflasi, karena saat terjadi inflasi jumlah ekuitas tidak terpengaruh, sehingga tidak dapat dijadikan perbandingan dengan tahun sebelumnya.

\section{Pengaruh Ukuran Perusahaan Terhadap Harga Saham}

Berdasarkan hasil uji (t) di peroleh bahwa thitung < ttabel dan nilai sig $>0,05$ sehingga Ukuran Perusahaan secara parsial tidak berpengaruh dan tidak signifikan terhadap terhadap Harga Saham pada perusahaan sub sektor Perhotelan Restoran dan Pariwisata yang terdaftar di Bursa Efek Indonesia 2014-2018.

Hasil ini sejalan dengan penelitian Lailatus, 2014 bahwa ukuran perusahaan tidak berpengaruh secara signifikan terhadap harga saham. Perusahaan yang berukuran lebih besar akan memiliki lebih banyak aktiva, sehingga perusahaan-perusahaan besar akan cenderung beroperasi pada tingkat yang maksimal. Perusahaan yang lebih besar seharusnya memiliki kesempatan yang lebih lebih besar pula untuk dapat mempertahankan harga saham dan bahkan menaiikkan harga sahamnya di pasar. Investor beranggapan bahwa perusahaan yang besar tidak selamanya dapat memberikan tingkat return yang besar begitu pula juga sebaliknya perusahaan kecil tidak menutup kemungkinan dapat memberikan tingkat return yang tinggi bagi para investornya. Hal inilah yang menjadikan ukuran perusahaan tidak berpengaruh secara signifikan terhadap harga saham.

\section{Pengaruh Debt To Equity Ratio Terhadap Harga Saham}

Berdasarkan hasil uji (t) di peroleh bahwa thitung > tabel dan nilai sig $<0,05$ sehingga Debt To Equity Ratio secara parsial berpengaruh dan signifikan terhadap terhadap Harga Saham pada perusahaan sub sektor Perhotelan Restoran dan Pariwisata yang terdaftar di Bursa Efek Indonesia 2014-2018.

Hasil ini sejalan dengan penelitian Nordiana, A \& Budiyanto (2017) menunjukkan bahwa debt to equity ratio berpengaruh signifikan terhadap harga saham. Jika debt to equity ratio (DER) perusahaan tinggi, ada kemungkinan harga saham perusahaan akan rendah karena jika perusahaan memperoleh laba, perusahaan cenderung untuk menggunakan laba tersebut untuk membayar utangnya dibandingkan dengan membagi dividend, hal tersebut membuat minat investor untuk menanamkan modalnya di perusahaan menjadi rendah, hal ini akan membuat harga saham juga akan turun.

\section{KESIMPULAN DAN SARAN}

Kesimpulan

Berdasarkan hasil penelitian dan pembahasan tentang pengaruh Return On Equity, Ukuran Perusahaan, Debt to Equity Ratio terhadap Harga Saham dapat ditarik kesimpulan bahwa:

1. Return On Equity secara parsial tidak berpengaruh dan tidak signifikan terhadap terhadap Harga Saham pada perusahaan sub sektor Perhotelan Restoran dan Pariwisata yang terdaftar di Bursa Efek Indonesia 2014-2018.

2. Ukuran Perusahaan secara parsial tidak berpengaruh dan tidak signifikan terhadap terhadap Harga Saham pada perusahaan sub sektor Perhotelan Restoran dan Pariwisata yang terdaftar di Bursa Efek Indonesia 2014-2018. 
3. Debt To Equity Ratio secara parsial berpengaruh dan signifikan terhadap terhadap Harga Saham pada perusahaan sub sektor Perhotelan Restoran dan Pariwisata yang terdaftar di Bursa Efek Indonesia 2014-2018.

4. Return On Equity, Ukuran Perusahaan dan Debt To Equity Ratio secara simultan berpengaruh terhadap Harga Saham Saham pada perusahaan sub sektor Perhotelan Restoran dan Pariwisata yang terdaftar di Bursa Efek Indonesia 2014-2018.

Saran

1. Bagi peneliti selanjutnya diharapkan tidak hanya menggunakan sampel perusahaan Sub sektor Perhotelan, Restoran dan Pariwisata yang ada di Bursa Efek Indonesia dan sebaiknya menambah periode penelitian agar penelitian lebih luas dan lebih memperhatikan variabel independen maupun variabel dependen yang akan diteliti.

2. Bagi Universitas Prima Indonesia Medan supaya lebih teliti dalam mengoleksi referensi buku serta jurnal yang akurat dalam penelitian ini

\section{DAFTAR PUSTAKA}

Ali dan Rodoni. 2014. Manajemen Keuangan Modren. Ed. Asli, Jakarta: Mitra Wacana Media Ari.

Utari, D, Purwanti, A, \& Prawironegoro, D. 2014. Manajemen Keuangan, Kajian Praktik dan Teori dalam Mengelola Keuangan Organisasi Perusahaan. Ed. Revisi, Jakarta: Mitra Wacana Media

Darmadji dan Fakhruddin. 2015. Pasar Modal Indonesia Pendekatan Tanya Jawab. Ed.3, Jakarta: Salemba Empat.

Egam, G. E. Y, Ventje, I. dan Pangerapan, S. 2017. Pengaruh Return On Assets (ROA), Return On Equity (ROE), Net Profit Margin (NPM) dan Earning Per Share (EPS) terhadap harga saham perusahaan yang tergabung dalam indeks LQ45 Di Bursa Efek Indonesia periode tahun 2013-2015. Junal Emba, Vol 5, No 1, hal 105-114.

Ghozali. 2013. Aplikasi Analisis Multivariete Dengan Program IBM SPSS 23. Cetakan ke-7, Semarang: UNDIP

Houston, Brigham. 2010. Dasar-Dasar Manajemen Keuangan, Jakarta : Salemba Empat.

Kamaludin. Dan Indriani, Rini. 2012. Manajemen Keuangan (Konsep Dasar dan Penerapannya). Cetakan kedua.Bandung: CV.Mandar Maju.

Kasmir. 2012. Analisis Laporan Keuangan. Jakarta: Rajawali Pers.

Kodrat Sukardi David, 2010 . Manajemen Investasi, Ed Pertama,Yogyakarta : Graha Ilmu.

Nordiana, A dan Budiyanto. 2017. Pengaruh DER, ROA dan ROE terhadap harga saham pada perusahaan food and beverage. Jurnal Ilmu dan Riset Manajemen, Vol. 6, No. 2, hal 1-16.

Nugraha, R. D. dan Sudaryanto, B. 2016. Analisis Pengaruh DPR, DER, ROE, dan TATO Terhadap Harga Saham (Studi Kasus pada Perusahaan Industri Dasar dan Kimia 
yang Terdaftar di BEI Periode 2010-2014). Diponegoro Journal Of Management, Vol 5, No 4, hal 1-12.

Ratih, Dorothea, E.P Apriatni dan Saryadi. 2013. Pengaruh EPS, PER, DER dan ROE Terhadap Harga Saham Pada Perusahaan Sektor Pertambangan Yang Terdaftar Di Bursa Efek Indonesia (BEI) Tahun 2010-2012. Diponegoro Journal of Social and Politic, hal 1-12.

Riyanto, Bambang. 2009. Dasar-dasar Pembelanjaan Perusahaan, Ed.4, Cetakan Keenam, Yogyakarta: Universitas Gadjah Mada.

Sa'adah, Lailatus dan Kadarusman. 2014. Pengaruh Laba Akuntansi, Komponen Arus Kas, Ukuran Perusahaan Terhadap Harga Saham pada Perusahaan Kelompok LQ 45 yang Listing di Bursa Efek Indonesia. Jurnal Manajemen dan Akuntansi, Vol. 3, No. 2.

Sartono,Agus. 2012. Manajemen Keuangan Teori dan Aplikasi, Ed. 4,Yogyakarta : BPFE Sjahrial Dermawan , 2011. Analisis Laporan Keuangan,Ed. 2, Jakarta : Mitra Wacana Media.

Sitanggang, J. P. 2013. Manajemen Keuangan Perusahaan Lanjutan. Edisi Pertama. Jakarta: Mitra Wacana Media.

Sjahrial, Dermawan, 2009. Manajemen Keuangan. Edisi Tiga. Jakarta: Mitra Wacana Media.

Sugiyono. 2017. Metode Penelitian Kuantitatif, Kualitati, dan R\&D. Bandung: Alfabeta. Sumarsan,Thomas, 2013 . Sistem Pengendalian Manajemen Konsep, Aplikasi, dan Pengukuran Kinerja, Ed 2, PT. Indeks.

Viandita, T. O, Suhadak, \& Husaini, A, 2013. Pengaruh Debt Ratio (DR), Price to Earning Ratio (PER), Earning Per Share (EPS), dan Size Terhadap Harga Saham (Studi pada Perusahaan Industri yang Terdaftar Di Bursa Efek Indonesia). Jurnal Administrasi Bisnis (JAB), Vol. 1, No. 2, hal. 113-121.

Weston, J. F. dan Thomas E. C. 2011. Manajemen Keuangan. Jakarta: Binarupa Aksara.

Zaki, M, Islahuddin, \& Shabri, M. 2017. Pengaruh Profitabilitas, Leverage Keuangan dan Ukuran Perusahaan Terhadap Harga Saham (Studi Pada Perusahaan Manufaktur yang Terdaftar di Bursa Efek Indonesia Periode 2005-2014). Jurnal Megister Akuntansi, Vol. 6, No. 2, hal 58-66. 